\title{
Revista da Seção Judiciária do Rio de Janeiro

\section{O PAPEL DAS SERVENTIAS EXTRAJUDICIAIS NO PROCESSO DE DESJUDICIALIZAÇÃO: UMA ANÁLISE DO ACESSO À JUSTIÇA PELA MITIGAÇÃO DA CULTURA DO LITÍGIO}

\section{THE ROLE OF EXTRAJUDICIAL SERVICES IN THE DEJUDICIALIZATION PROCESS: AN ANALYSIS OF ACCESS TO JUSTICE THROUGH MITIGATION OF THE CULTURE OF LITIGATION}

Adenilton Feitosa Valadares ${ }^{1^{*}}$

Resumo: $O$ artigo tem por objetivo despertar reflexões acerca dos efeitos da aplicação dos meios alternativos de resolução de conflitos no âmbito do ordenamento jurídico brasileiro, mormente, no que se refere às serventias extrajudiciais. A partir da análise da doutrina e de entendimentos jurisprudenciais, vê-se como a máquina do Poder Judiciário passou e ainda passa por desafios, especialmente, os relacionados à sobrecarga por conta de seu uso descomedido pelos cidadãos. Assim, com base no levantamento bibliográfico de doutrinas especializadas no tema bem como nos dados obtidos através do estudo de dados qualitativo, os resultados e conclusões sugerem que a adoção do modelo "multiportas" pelos tabeliães e oficiais de registro é uma questão que merece ser cada vez mais aprimorada e aplicada. Com efeito, a busca pela desjudicialização com a transferência de competências pode ser uma das soluções para a promoção da mitigação da cultura do litígio excessivo.

Palavras-chave: Serventias extrajudiciais. Poder Judiciário. Desjudicialização.

Abstract: The article aims to awaken reflections on the effects of the application of alternative means of conflict resolution within the scope of the Brazilian legal system, especially with regard to extrajudicial services. From the analysis of the doctrine and jurisprudential understandings, we see how the machinery of the Judiciary Power has gone through and still faces challenges, especially those related to overload due to its excessive use by citizens. Thus, based on the bibliographic survey of specialized doctrines on the topic as well as the data obtained through the study of qualitative data, the results and conclusions suggest that the adoption of the "multiport" model by notaries and registry officers is an issue that deserves to be improved and applied. Indeed, the search for legalization with the transfer of competences may be one of the solutions for promoting the mitigation of the culture of excessive litigation.

\footnotetext{
1* Especialização em Direito Penal pela Faculdade Internacional Signorelli, Brasil (2014). DelegatárioConcursado do Cartório de Registro de Títulos e Documentos e PJ de Feira de Santana, Brasil.
} 
Keywords: Extrajudicial services. Judiciary power. Dejudicialization.

Recebido em: 07/05/2021

Aceito em:14/05/2021

\section{INTRODUÇÃO}

Este artigo analisa o papel das serventias extrajudiciais no processo de desjudicialização ${ }^{2}$ e a consequente mitigação do paradigma da litigiosidade. Busca em seu objeto de estudo uma possível resposta ao problema de instabilidade no ordenamento jurídico evidenciado por conta da "sobrecarga" do Poder Judiciário, além de despertar reflexões quanto ao impacto da utilização dos meios alternativos de solução de conflitos e como isso repercute no comportamento social dentro do contexto jurídico.

Este trabalho pretende demonstrar como, atualmente, as serventias extrajudiciais são relevantes meios de desjudicialização que podem atenuar a alta concentração de litígios no Poder Judiciário, através da transferência de competências. Tem como hipótese denotar a maneira na qual as serventias extrajudiciais configuramse enquanto instrumentos que, paulatinamente, se tornarão perceptíveis para realização de atos em curto espaço de tempo, pautados pela razoabilidade, celeridade, qualidade dos serviços eletrônicos e confiança, satisfazendo os interesses e direito das partes. Tais práticas impactarão no comportamento social e, consequentemente, na significativa redução de números de processos na Justiça, assegurando o cumprimento de direitos.

O referencial teórico foi desenvolvido ancorado nos autores clássicos, a exemplo de Humberto Theodoro Júnior, sem olvidar de outros com viés administrativo

\footnotetext{
${ }^{2}$ Hodiernamente, há um significativo avanço nas demandas judiciais no Brasil, dividindo opiniões de alguns autores constitucionalistas, a exemplo do professor Luiz Jorge Werneck Vianna que vê a necessidade da judicialização, em posição contrária se manifesta o professor José Ribas Vieira. Em defesa intermediária surge o Ministro Luís Roberto Barroso. Nesse contexto, surge o termo desjudicialização que é um neologismo utilizado pela comunidade jurídica para reflexões acerca de outras formas de solução das demandas sociais, que não alcancem o Judiciário.
} 
da atividade notarial e registral, trazendo à análise as lições do Professor Luiz Guilherme Loureiro, hoje uma das maiores referências nessa área extrajudicial.

A metodologia adotada é a qualitativa nas coletas de informações e no tratamento destas por meio de seleção de conteúdo temático, por meio do qual analisa apanhados de documentos e casos relevantes, com o objetivo de promover 0 desenvolvimento do estudo das serventias extrajudiciais no processo de desjudicialização. Ademais, investiga-se a jurisprudência, com a seleção de julgados em decisões proferidas em casos concretos no tocante à atuação e configuração do tabelião e do oficial de registro.

O trabalho abordará como ponto inicial o viés conceitual dos direitos notarial e registral. Será, brevemente, considerada a natureza jurídica das serventias extrajudiciais, sua finalidade e especificidade, de atuação, a fim de averiguar seus benefícios e abordagem no sistema jurídico brasileiro.

Vislumbrar-se-á suas características essenciais para a formalização da vontade das partes, prevenção de litígios e pacificação social, dentre as quais encontram-se a delegação estatal, controle da legalidade ou "qualificação", intervenção nos negócios jurídicos de natureza privada, assessoramento e mediação, imparcialidade e independência.

Através do percurso delineado, pretende-se demonstrar a importância e utilidade dos notários e registradores enquanto profissionais cujo dever, dentre outros, é conferir a proteção aos interesses das partes, marcado pela prática igualitária e imparcial.

Além disso, pretende-se evidenciar como os cartórios impactam a cultura jurídica, cada vez mais, através de recentes levantamentos, que corroboram para o fluxo das atividades com vistas à harmonização social.

Finalmente, dissertar-se-á a respeito da regulamentação da atividade de mediação e conciliação nos Ofícios de Notas e de Registros através do Provimento no 67/2018, elaborado pelo Conselho Nacional de Justiça, que almeja uma prática 
pautada pela neutralidade e sigilo, ao conferir uma solução mais célere às partes, além de promover sua participação na construção do direito.

\section{OS DIREITOS NOTARIAL E REGISTRAL: CONCEITOS, NATUREZA JURÍDICA, FINALIDADE E ESPECIFICIDADE}

Preliminarmente, é importante destacar que os direitos notarial e registral objetivam o desenvolvimento e aprimoramento das relações jurídicas, através das normas, princípios e instituições, com o fito de distanciarem-se de sua anormalidade - teratologia -, que resultaria na geração de conflitos e desavenças na defesa das pretensões resultantes das referidas relações.

Salienta-se que se consubstanciam em ramos do direito que não tem por propósito, via de regra, a resolução de litígios, como o faz o direito processual. Pelo contrário, são voltados a esquivar-se do surgimento de conflitos.

Luiz Guilherme Loureiro (2019, p. 50) pontua nesse sentido que:

[...] o direito processual é um direito restaurador ou reparador que permite a aplicação das normas de direito substantivo a um determinado caso concreto; enquanto o segundo é preventivo e busca o estabelecimento da presunção de certeza e validez dos atos e negócios jurídicos, não apenas em relação aos demais particulares, mas também em face do Estado.

Seguindo essa esteira, afirma-se que o direito notarial e o direito registral têm por similitude e propósito precípuo a segurança jurídica preventiva. Quanto às divergências, ressalta-se que o tabelião é o profissional que está presente no momento da tessitura do negócio jurídico.

Ele atende as partes antes mesmo de sua concretização, ouvindo e cientificando-se das pretensões dos envolvidos, de maneira a aconselhar, criar e autorizar, solenemente, tomando por base as cautelas legais para a perfeição, validade e eficácia do que vier a ser pactuado.

É um jurista de confiança e de livre escolha das partes, cujas ações compreendem a formalização da vontade, intervenção nos atos e negócios jurídicos e autenticação de fatos. 
Angelo Volpi Neto (2018, p. 57) confessa

Descrever sobre a história da profissão notarial é flertar com o perigo de perder-se dentro da trajetória da civilização humana (...). Desde os mais remotos povos encontramos fragmentos desta profissão, cujo contexto é indissociável do desenvolvimento do direito, da cultura da ordem social e econômica.

Celso Fernandes Campilongo (2014, p. 105) reforça, nesse sentido, que

[...] em seu conjunto, o sistema jurídico é depositário de confiança necessária à reprodução da ordem social. A relevância dessa "função de confiança" para a economia é extraordinária. Ela multiplica as possibilidades de transações. Nos negócios imobiliários, a necessidade dessa "função de confiança" é redobrada. A magnitude das transações, o prazo dos contratos, a relevância social dos ativos, a complexidade das tratativas, a utilização da propriedade imóvel como garantia de outros negócios, enfim, tudo exige cautelas redobradas.

Nesse ínterim, informa-se o notariado latino adota o modelo da maior parte dos países europeu. Isso significa que o notário intervém nos assuntos de maior relevância, para assegurar a tutela preventiva de um direito. O referido modelo encontra-se consagrado na Constituição da República do Brasil de 1988, em seu artigo 236.

Em contrapartida, ao registrador incumbe a publicidade jurídica de fatos ou situações, no entanto, de difícil especificação, posto que:

Como foram criados diversos tipos de Registros, para a publicidade jurídica de fatos ou situações jurídicas de naturezas diversas $[\ldots]$, existem várias espécies de registradores, com atribuições e competências diferentes. A diversidade de Registros e registradores torna difícil afirmar a existência de um direito registral único e, em regra, a doutrina trata de diversos direitos registrais, como o imobiliário, o de pessoas naturais, 0 de pessoas jurídicas, etc. (LOUREIRO, 2019, p. 51).

Nota-se, inclusive, que, por se tratar de atribuição, sendo, portanto, obrigatória, os profissionais titulares das serventias extrajudiciais têm o dever de atender as demandas de seus usuários quando solicitadas, mormente, por não se tratar de mera faculdade, não podendo prestar os serviços de maneira arbitrária. 
No que se refere à finalidade das instituições do notariado e dos registros, face ao que dispõe os artigos $1^{\circ}$ e $3^{\circ}$ da Lei no 8.935/94 (que regulamenta o artigo $236^{3}$ da Constituição da República, dispondo sobre serviços notariais e de registro), depreende-se, então, que está ligada à organização técnica e administrativa destinada a garantir a publicidade, autenticidade, eficácia e segurança dos atos jurídicos, com o elemento da fé pública.

Milton Fernando Lamanauskas (2017, p. 159) assevera que

Notários e registradores (...) realizam uma atividade denominada de "qualificação". Os notários, para instrumentalizar a vontade das partes; os registradores para conceder a inscrição no fólio registral visando a constituição e a preservação de direitos, quando nas especialidades imobiliárias, civil das pessoas jurídicas ou títulos e documentos; quando registradores civis das pessoas naturais, igualmente qualificam, para formalização e publicidade dos direitos da personalidade.

É importante ressaltar, outrossim, que as serventias extrajudiciais não possuem personalidade jurídica, por se tratar de mero complexo de competências. Nesse ponto, é imperioso pontuar que o detentor da personalidade jurídica é o notário ou registrador: ele não manifesta a vontade/ação estatal e também não se trata de um órgão ou funcionário público stricto sensu. A jurisprudência, inclusive, é assente e cristalina nesse sentido[ $\left.{ }^{4}\right]$.

3 Art. 236. Os serviços notariais e de registro são exercidos em caráter privado, por delegação do Poder Público.

${ }^{4}[]$ Conforme é possível vislumbrar nas notas aqui elencadas, citam-se os seguintes julgados para fins de melhor entendimento sobre como é tratado na jurisprudência brasileira:

Medida cautelar de exibição de documentos. Autora que pretende a exibição da documentação fornecida por apresentante, quando do protesto de dois cheques por ela emitidos. Sentença de improcedência. Apelação. Ilegitimidade dos cartórios extrajudiciais para figurarem no polo passivo de demanda judicial, por isso que não ostentam personalidade jurídica ou judiciária e representam apenas centros administrativos de desenvolvimento das atividades notariais e de registro, na forma, aliás, do artigo 22, da Lei 8935/94, que estabelece a responsabilidade pessoal dos titulares de serviços notariais e de registro, não reconhecida aos cartórios, personalidade jurídica ou judiciária. Extinção do processo em resolução do mérito, prejudicado o apelo da autora. (TJ-RJ APL: 00001748320138190087 RIO DE JANEIRO ALCANTARA REGIONAL SAO GONCALO 2 VARA CIVEL, Relator: MAURICIO CALDAS LOPES, Data de Julgamento: 07/05/2014, DÉCIMA OITAVA CÂMARA CÍVEL, Data de Publicação: 08/05/2014) (grifo nosso) 
Assim, constata-se que o cartório consiste um feixe de atribuições ou competências criadas por lei, não sendo constituído, portanto, por elementos configuradores de empresa. Frisa-se que o estabelecimento trata de uma universalidade de direito, não sendo a serventia extrajudicial alienável. Não é propriedade de seu titular e parte de seus bens é pertencente ao Estado, dentre os quais, os livros de notas e os documentos mantidos em arquivo. Por fim, não há intuito de lucro, não podendo o notário ou o registrador exercer a atividade em sociedade.

O profissional, em tela, tem como atribuição a instrumentalização da vontade das partes, concedendo sua fé pública a determinados atos para os quais os envolvidos desejem conferir autenticidade bem como a formalização, sempre em adequação aos parâmetros legais e com a cautela indispensável à prevenção de contendas judiciais.

\section{CARACTERÍSTICAS DAS FUNÇÕES NOTARIAIS E REGISTRAIS}

As funções exercidas pelas serventias extrajudiciais podem ser caracterizadas sob o prisma de uma função pública ante a iniciativa privada, gozando os notários e registradores de independência no exercício de suas atribuições.

MANDADO DE SEGURANÇA. INSCRIÇÃO NO CNPJ. REGISTRO CIVIL DAS PESSOAS NATURAIS. TABELIÃO. VINCULAÇÃO À PESSOA FÍSICA. NOVO REGISTRO. POSSIBILIDADE. APELAÇÃO PROVIDA. 1. Os serviços notariais e de registro foram definidos no artigo 236 da Constituição Federal, regulamentado pela Lei no 8.935/94. Da interpretação sistemática dos dispositivos conclui-se que o serviço notarial e de registro é prestado por pessoa física, não tendo o cartório personalidade jurídica própria. 2. No caso, o impetrante foi investido no cargo público em caráter originário, não possuindo qualquer vinculação com o notário anterior, posto que o registro por esse efetuado junto à Receita Federal refere-se à pessoa física e não à serventia. 3. Não há regramento específico que impeça a nova inscrição em decorrência da mudança de titularidade. 4. Mostra-se abusiva a negativa da autoridade impetrada em negar a possibilidade de nova inscrição, tendo em vista a finalidade do cadastro de facilitar o controle e a fiscalização da arrecadação dos tributos devidos, tais como encargos trabalhistas e previdenciários. 5. Apelação provida. (TRF-3 - AMS: 00131486720154036100 SP, Relator: DESEMBARGADORA FEDERAL MÔNICA NOBRE, Data de Julgamento: 05/07/2017, QUARTA TURMA, Data de Publicação: e-DJF3 Judicial 1 DATA:30/08/2017, grifo nosso) 
Nesse contexto, são civilmente responsáveis por todos os prejuízos que causarem a terceiros, por culpa ou dolo, pessoalmente, pelos substitutos que designarem ou escreventes que autorizarem, assegurado o direito de regresso, a rigor do que dispõe o artigo 22 da Lei no 8.935/94 (que regulamenta o art. 236 da Constituição da República, dispondo sobre serviços notariais e de registro).

\subsection{Função Delegada pelo Estado}

A fé pública pertence ao Estado. A segunda parte do artigo $3^{\circ}$ da Lei $n^{\circ}$ 8.935/94 informa, de maneira expressa, ao afirmar que aos profissionais atuantes nas serventias extrajudiciais "é delegado o exercício da atividade notarial e de registro".

A Constituição da República de 1988, seguindo essa esteira, aduz, em seu artigo 236, que "os serviços notariais e de registro são exercidos em caráter privado, por delegação do Poder Público".

Em síntese, é válido ressaltar, o Estado não delega suas funções, por assim dizer, mas o seu efetivo exercício. Consoante Luiz Guilherme Loureiro (2019, p. 60), "tratam-se de funções públicas desempenhadas não por funcionários públicos em sentido estrito, mas por agentes públicos na categoria de particulares em contribuição com a Administração".

Consequentemente, há o controle do Estado através do Poder Judiciário no que diz respeito à atuação dos tabeliães e registradores, além da disciplina estabelecida entre os agentes e o poder delegante.

Ao contrário do que ocorre na simples transferência de atribuições no ato administrativo homônimo bem como nos casos de descentralização do serviço público, in casu, o Estado transfere, com caráter de definitividade, a competência exclusiva para a formalização da vontade, intervenção nos atos e negócios jurídicos e autenticação de fatos.

Trata-se de uma transferência desprovida de caráter transitório. Sua perdurabilidade tem por objeto competências específicas, ao contrário do que se verifica no mero trespasse. Não cabe falar em contratos de concessão e permissão. 
O artigo 39 da Lei no 8.935/94 corrobora com a explanação supra, ao comunicar que a delegação a notário ou a oficial de registro será extinta, dentre outros, por morte; aposentadoria facultativa; invalidez; renúncia; perda por sentença judicial transitada em julgada ou por decisão decorrente de processo administrativo instaurado pelo juízo competente; invalidez; renúncia.

Ainda, diz-se que a competência do notário é irrenunciável, não podendo o profissional abster-se de seu poder-dever ou transferi-lo a terceiros. Igualmente, o ente estatal é impedido de avocar (atrair para si) a atribuição imposta legalmente e constitucionalmente ao notário.

\subsection{Controle da Legalidade}

Em um período de tempo marcado pela interdisciplinaridade, por óbvio, é possível afirmar que a ciência jurídica não é suficiente para atingir os escopos da função administrativa. Mormente, por se tratar esta última de uma atividade voltada à finalidade política.

O controle da função notarial e de registro pressupõe a detecção de falhas e aprimoramento setorial, o que advém do planejamento, organização, direção e controle. Conforme já explanado alhures, mesmo não se tratando de um servidor público, o titular das serventias extrajudiciais é um agente público que exerce poderes do Estado, razão pela qual está sujeito à fiscalização e ao controle, segundo mecanismos próprios da Administração Pública, que será realizado pelo Poder Judiciário.

O referido controle a que se submetem os notários e registradores é denominado "qualificação". Segundo considerações feitas por Letícia Franco Maculan Assumpção (2019), "o Poder Judiciário tem o poder-dever de exercer o controle sobre os serviços notariais e de registro e [...] o titular dos serviços tem o direito de ser devidamente controlado, de ser orientado sobre a melhor forma de proceder para a instalação do serviço $[\ldots]^{\prime \prime}$. 
NO PROCESSO DE DESJUDICIALIZAÇÃO:...

Tal intervenção está de acordo com a compreensão administrativista, com fundamento na Carta da República e na gnosiologia, que pretende a interação entre os diversos ramos do saber.

\subsection{Intervenção nos Negócios Jurídicos Particulares}

Os já mencionados artigos $1^{\circ}$ e $3^{\circ}$ da Lei no $8.935 / 94$ comunicam o dever do tabelião e do oficial de registro de velar pela publicidade, eficácia, segurança dos atos e negócios jurídicos dos particulares bem como por sua autenticidade.

Essa ingerência é de fundamental importância para a manutenção da proteção das relações econômicas estabelecidas entre os indivíduos bem como para as transações jurídicas de maneira geral.

O mecanismo de segurança preventiva deve se fazer presente nos atos de conclusões contratuais assim como nos atos de publicidade registral, com o objetivo de resguardá-los frente a possíveis violações e suas consequências.

Segundo preleciona Luiz Guilherme Loureiro (2019, p. 63),

[...] os países de direito continental [...] privilegiam a intervenção prévia de agentes estatais especializados a fim de evitar violações ou lesões a direitos e interesses tutelados pela lei, que podem ser causados, por exemplo, por vícios formais dos atos e negócios jurídicos, fraude, dolo ou lesão proveniente da conduta da parte mais forte no contrato, ou pela falta da publicidade exigida por lei para que tais negócios produzam efeitos materiais (...).

No mesmo sentido, José Flávio Bueno Fischer (2018, p. 37):

A única forma de proteger os menos favorecidos em uma relação negocial é a pormenorizada formalização através da necessária intervenção de um terceiro de confiança que garanta o equilíbrio entre as partes. Somente o notário, com sua imparcialidade, será capaz de aconselhar o cidadão comum, aquele que não possui grandes recursos e que, portanto, não tem fácil acesso a outros eventuais instrumentos que o possam proteger. É ele, o notário, quem indicará, com imparcialidade, o melhor caminho jurídico a ser seguido, formalizando, com segurança jurídica e legalidade, o negócio jurídico. 
Assim, é possível a obtenção da justiça contratual, de maneira que haja uma diminuição significativa da cultura do litígio, dentre outros benefícios, que corroboram para a conservação e perenidade dos atos cartoriais bem como para a segurança jurídica dos contratos realizados em caráter privado.

\subsection{Função de Assessoramento e Mediação}

Não há objeção quanto à afirmativa de que, ainda hoje, o Poder Judiciário ocupa uma posição de centralidade no Ordenamento Jurídico. Tal asserção encontra respaldo, sobretudo, na Constituição da República de 1988, que assegura a inafastabilidade da jurisdição. Entretanto, o Poder Judiciário encontra-se sobrecarregado.

Nessa senda, "na medida em que Executivo e Legislativo sofrem brutal e generalizada descrença, muitas esperanças de afirmação e garantia de direitos acabaram transferidas para o Judiciário e agravaram a sobrecarga" (Campilongo, 2014, p. 130).

Apesar das distinções entre o processo estatal e o modelo "multiportas" de acesso à justiça, é válido afirmar que o objetivo a ser perseguido por ambos é, principalmente, a pacificação social através do acesso ao Ordenamento Jurídico.

$E$, no que importa às serventias extrajudiciais, o Provimento no 67/2018 do Conselho Nacional de Justiça, conforme será trabalhado adiante, consolidou o direito como garantia de liberdades, visando à participação dos envolvidos na construção do juízo, por meio da discussão e aceitação do que vier a ser acordado e eleição da forma.

Dessa forma, o notário ou o registrador atua na redução de processos judiciais com a formalização de negócios jurídicos, tomando, sempre, as devidas cautelas, para não desencadear invalidade, ineficácia ou cláusulas oponentes ao ordenamento.

Gustavo Paula Leite Rocha Júnior (2017, p. 69) sustenta que: 
$\mathrm{Na}$ qualidade de assessor das partes, o tabelião atua na diminuição de pontos de conflito, permitindo que o negócio seja concretizado e antecipando questões que gerariam conflitos no futuro. Não são raras as situações, em que, as partes não estão em conformidade quanto a todos os aspectos do negócio e chegam a soluções ou determinações em função da intervenção do notário, denotando uma participação na solução de conflitos, ainda que na forma de negociação.

Dessa forma, pode-se averiguar que esse profissional é um colaborador, conjuntamente com aqueles que exercem a mediação e a conciliação na seara judicial, facilitando a comunicação entre aqueles que recorrem ao sistema "multiportas" e a formulação e aceitação de propostas, com o uso da capacidade técnica e da confiança.

\subsection{Imparcialidade e Independência}

A função notarial e registral possui caráter público, de modo que possui a autoridade estatal. Dessa forma, deve ser exercida de maneira imparcial e independente, não havendo que se falar em hierarquia entre aqueles que se encontram a serviço do Estado.

O artigo 28 da Lei no 9.835/94 é claro ao aduzir que "os notários e oficiais de registro gozam de independência no exercício de suas atribuições (...)", devendo, dentre outros, "atender as partes com eficiência, urbanidade e presteza" (artigo 30, da Lei no 9.835/94).

Isso significa que os profissionais são imparciais e, no exercício do seu múnus, é essencial a tratativa para com as partes no sentido de defender igualmente seus interesses, sem favorecimentos de qualquer natureza, não obstante haja pressões ou influências externas.

É conveniente evidenciar que a característica da imparcialidade não salvaguarda apenas os interessados, como também os terceiros, estando, assim, em consonância com as determinações do direito negocial, equiparando e protegendo as partes, inclusive as consideradas hipossuficientes. 
Da mesma forma que ocorre com as atividades ligadas à mediação, é, precisamente, a característica, em tela, que distingue os notários e registradores de outros profissionais liberais no universo jurídico. Destarte, isso os torna ideais no que diz respeito à intervenção para prevenir e solucionar extrajudicialmente as controvérsias, com a devida observância de suas competências previstas em lei.

\section{A DESJUDICIALIZAÇÃO COMO FORMA DE ACESSO À JUSTIÇA NO ÂMBITO DAS SERVENTIAS EXTRAJUDICIAIS}

Desde os primórdios de sua existência, o ser humano vive em contínuo conflito, mormente, por ter como inerente à sua natureza o antagonismo e as disputas característica da história das sociedades.

Os choques de interesses, nos tempos primordiais, eram caracterizados pelo uso da força física entre contendores (o que, contemporaneamente e sob uma nova roupagem, ficou conhecido e regularizado como o instituto da autotutela).

Com o surgimento do ente estatal e, com o passar do tempo, estabeleceuse que a solução dos conflitos passaria ao monopólio do Estado. Assim, a aplicação da lei - jurisdição -, regida pelo princípio da substitutividade, ficou sob a incumbência do Estado-juiz, que, conforme apontado pela própria nomenclatura, substituiu as partes na solução dos conflitos para corresponder à exigência da imparcialidade e da imperatividade. As decisões judiciais passaram, então, a ter força imperativa, obrigando os litigantes.

Nesse ponto, é válido destacar a previsão contida na Constituição da República de 1988, em seu artigo 50, inciso XXXV, da qual derivou o princípio da inafastabilidade da jurisdição. $O$ dispositivo assegura que a lei não excluirá da apreciação do Poder Judiciário a lesão ou ameaça de lesão a direito.

Nas palavras de Humberto Theodoro Júnior (2015, p. 171),

[...] é fora de dúvida que a atividade de dirimir conflitos e decidir controvérsias é um dos fins primários do Estado. Mas, desde que privou os cidadãos de fazer atuar seus direitos subjetivos pelas próprias mãos, a ordem jurídica teve que criar para os 
particulares um direito à tutela jurídica do Estado. E este, em consequência, passou a deter não apenas o poder jurisdicional, mas também assumiu o dever de jurisdição (grifo do autor).

Dessa forma, tem-se que, hodiernamente, em vez de conceber a jurisdição enquanto poder é preferível concebê-la como uma função estatal secundária, instrumental e provocada, dadas a declaração e realização da mens legis de forma prática, diante de uma situação jurídica controvertida.

Todavia, ressalta-se que o amplo acesso ao Poder Judiciário desencadeou o abuso da garantia constitucional da inafastabilidade da jurisdição bem como o elevado crescimento da cultura do litígio, o que inviabilizou e, ainda inviabiliza, o uso da máquina judiciária como único meio de solução de conflitos.

Os números do Conselho Nacional de Justiça (CNJ) relativos ao ano-base de 2018, por exemplo, apontam uma despesa no montante de $\mathrm{R} \$ 93.725 .289 .276,00$ (noventa e três bilhões, setecentos e vinte e cinco milhões, duzentos e oitenta e nove mil, duzentos e setenta e seis reais), com um total de 31.883.392 (trinta e um milhões, oitocentos e oitenta e três mil, trezentos e noventa e dois) processos baixados e 28.052.965 (vinte e oito milhões, cinquenta e dois mil, novecentos e sessenta e cinco) casos novos.

Assim, é inarredável deduzir que o Estado tem falhado em sua missão pacificadora, principalmente, pela sobrecarga de tribunais bem como pelas despesas exorbitantes seja com os litígios seja com os recursos humanos. Não se pode olvidar, também, que o excesso de formalismo e o apego aos escopos do processo dificultou o fluxo das atividades com vistas a harmonizar a sociedade.

Segundo Venceslau Tavares Costa Filho (2016, p. 169),

A primeira sobrecarga diz respeito ao excesso de fragmentação das ordens normativas, que redundam na caracterização do "direito como único meio de tratamento de conflitos realmente significativo a sociedade complexa". Tal sobrecarga do direito resulta em uma sobrecarga do Estado, porquanto a pretensão moderna de monopólio estatal da jurisdição faça com que o Estado e o Direito sejam dotados de funções muito próximas, ou quase idênticas. É por isto que, no âmbito da chamada "divisão" de poderes estatais, verifica-se "uma sobrecarga dos órgãos encarregados das decisões concretas, mormente o poder judiciário e os diversos conselhos e comissões do executivo". 
A Resolução no 125/2010, prevendo o uso cada vez mais descomedido do Poder Judiciário, instituiu, através de seu artigo $1^{\circ}$, parágrafo único, que "aos órgãos judiciários incumbe, (...) antes da solução adjudicada mediante sentença, oferecer outros mecanismos de soluções de controvérsias, em especial os chamados meios consensuais, como a mediação e a conciliação, bem assim prestar atendimento e orientação ao cidadão".

Estabeleceu a referida Resolução, dessa maneira, a instalação de núcleos permanentes de métodos consensuais de solução de conflitos e a capacitação, treinamento e atualização de membros e servidores com o intuito de proporcionar eficiência operacional e a redução da excessiva judicialização de conflitos de interesses.

Vale manifestar, nesse tocante, o raciocínio de Celso Fernandes Campilongo (2014, p. 131), que, ao se referir à Resolução, em comento, posiciona-se contra esta enquanto gênese da implementação dos institutos da mediação e conciliação, por configurarem ambos institutos de tão antigos quanto sua própria prática:

Errôneo imaginar a Resolução n. 125 do CNJ tenha instituído a conciliação e a mediação entre nós. Nada impedia, antes dessa Resolução, solução e prevenção de litígios - sempre consensual e facultativa -, por livre e espontânea vontade de partes capazes e tendo por objeto, obviamente, "direitos patrimoniais disponíveis", ou seja, direitos que possam ser exercidos livremente pelos titulares. A Resolução n. 125 do CNJ apenas impulsionou, em corajoso e decisivo passo, a utilização desses meios alternativos de autocomposição de conflitos, de origem milenar. Conciliação e mediação são tão antigas quanto os conflitos que previnem ou solucionam.

O ideal da solução consensual de conflitos não se limita a determinados tipos específicos de direito, pelo contrário, é apresentado como um princípio norteador para o direito processual civil brasileiro, que prescreve o dever de promover, sempre que possível, a solução consensual de conflitos.

No âmbito das serventias extrajudiciais, a desjudicialização ou extrajudicialização dos conflitos é marcada pela transferência de competências do 
Poder Judiciário para órgãos extrajudiciais, especialmente para tabelionatos de notas e registros.

Venceslau Tavares Costa Filho (2016, p. 170) afirma que a tendência à desjudicialização tem 0 fito de solucionar questões nas quais se percebe a disponibilidade dos direitos das partes, contribuindo para a efetividade de seus direitos. Exemplos da referida tendência podem ser encontrados em alguns institutos, tais como o divórcio e o inventário extrajudiciais (Lei no 11.441/07).

Nesse ínterim, o atual Código de Processo Civil é claro ao definir, em seu artigo 733, que o divórcio consensual, a separação consensual e a extinção consensual de união estável, não havendo nascituro ou filhos incapazes e observados os requisitos legais, poderão ser realizados por escritura pública, da qual constarão as disposições de que trata o artigo 731.

O dispositivo lembra, ainda, em seu $\S 1^{\circ}$, que a escritura constitui título hábil para qualquer ato de registro, independentemente de homologação judicial, bem como para levantamento de importância depositada em instituições financeiras.

Destaca-se, por oportuno, que se os cônjuges não consentirem com a partilha do patrimônio, sobeja a possibilidade de ajuizamento de ação de partilha mesmo posteriormente à homologação do divórcio ou da separação.

Tal entendimento encontra respaldo no artigo 694 do Código de Processo Civil, porquanto "nas ações de família, todos os esforços serão empreendidos para a solução consensual da controvérsia".

Por simetria ao ato solene do casamento, é admissível que os interessados façam-se representar por procurador. A Resolução n 35/2007 do Conselho Nacional de Justiça reza, em seu artigo 37, que "o comparecimento pessoal das partes é dispensável à lavratura de escritura pública de separação e divórcio consensuais, sendo admissível ao(s) separando(s) ou ao(s) divorciando(s) se fazer representar por mandatário constituído, desde que por instrumento público com poderes especiais $[\ldots]^{\prime \prime}$. 
O supracitado dispositivo confere maior celeridade processual. $E$, não somente isso, frisa-se que, com a vigência do atual Código Processual, não há menção a regras de competência como ocorre com os atos judiciais. A Lei no 8.935/94 - "Lei dos Cartórios" -, que dispõe sobre serviços notariais e de registro, informa que "é livre a escolha do tabelião de notas, qualquer que seja o domicílio das partes ou o lugar de situação dos bens objeto do ato ou negócio".

Vale destacar que os dados apresentados pela Associação dos Notários e Registradores do Brasil (ANOREG/BR) levaram à conclusão de que as serventias extrajudiciais, além de configurarem serviços que nada custam ao Estado, beneficiam cidadãos em todos os municípios do país. Foram utilizados como parâmetros de pesquisa, dentre outros, a qualidade dos serviços eletrônicos e a confiança nas serventias.

Apontou-se que $88 \%$ (oitenta e oito por cento) dos pesquisados pelo Instituto Datafolha, no ano de 2015, consideram os cartórios as instituições mais confiáveis do Brasil, dentre todas as instituições públicas e privadas.

Além disso, desde a publicação da Resolução no 175/2013 - que dispõe sobre a habilitação, celebração de casamento civil, ou de conversão de união estável em casamento, entre pessoas de mesmo sexo -, já foram realizados mais de trinta e sete mil casamentos homoafetivos nos Registros Civis brasileiros.

Igualmente os serviços registrais possibilitaram a substituição de prenome e sexo com a publicação da Resolução no 73/2018 do CNJ. O caso foi suscitado por conta do julgamento da Ação Direta de Inconstitucionalidade 4275, em que, dando interpretação conforme a Constituição e o Pacto de São José da Costa Rica ao artigo 58 da Lei 6.015/73 (Lei de Registros Públicos), reconheceu "aos transgêneros que assim o desejarem, independentemente da cirurgia de transgenitalização, ou da realização de tratamentos hormonais ou patologizantes, o direito à substituição de prenome e sexo diretamente no registro civil".

Ademais, mais de quarenta mil paternidades socioafetivas foram reconhecidas e mais de cem mil reconhecimentos de paternidade já foram realizados, 
em consonância com a Resolução n $16 / 2012$ do $\mathrm{CNJ}$, que possibilitou que 0 ato fosse praticado diretamente nas serventias competentes para tanto.

Levando em consideração os serviços nos Tabelionatos de Notas, a desjudicialização ainda ocorreu de maneira mais simplificada, porquanto, por exemplo, a população deixou de levar um ano, em média, para se divorciar na Justiça, para fazer $\mathrm{o}$ ato no mesmo dia em um cartório. E não somente isso, a população deixou, também, de levar quinze anos para fazer o inventário judicial para fazer o ato em quinze dias na serventia.

Nesse tocante, ressalta-se que, desde 2007, a Lei no 11.441 tem facilitado a vida dos cidadãos brasileiros, ao permitir a realização do inventário e da partilha em Tabelionatos de Notas. Desde a publicação da referida lei até o ano de 2018, constatou-se que já foram realizados mais de um milhão de inventários no país, por meio de escritura pública, com celeridade e segurança.

Pelo exposto, pode-se depreender que os notários e registradores são instrumentos ativos e dinâmicos na seara da sistemática civilista, que tornam possível o cumprimento da lei de maneira correta, considerada a ontologia da ciência jurídica. A função delegada pelo Estado é, então, peça-chave para a efetiva observância do critério isonômico, segurança jurídica, autenticidade e publicidade da vontade dos envolvidos.

\section{O EXERCícIO dA MEdiAÇÃo PELO NOTÁRIO E PELO REGISTRADOR: 0 PROVIMENTO CNJ 67/2018}

Conforme alhures explanado, a morosidade da prestação jurisdicional tornou-se um grande desafio para o Poder Judiciário, mormente, por conta da garantia constitucional da inafastabilidade da jurisdição, descomedida pelo indivíduo, o que suscitou o princípio da razoável duração do processo.

Tendo em vista tamanha atribulação e suas consequências, o atual Código de Processo Civil - marcado por sua transconstitucionalização - passou a prever a solução do litígio em prazo razoável através do Sistema de Justiça "Multiportas". 
Gustavo Paula Leite Rocha Júnior (2017, p. 61) afirma que:

Dentre as diversas medidas para tentar viabilizar a solução mais célere das lides houve um incentivo à adoção de meios que não envolvam juízes, por isso chamados por alguns de meios alternativos ou adequados de solução de conflitos, o que se deu em nosso país pela edição da Lei de Arbitragem (Lei $n^{0}$ 9.307/1996), pelo fomento à conciliação (Leis nos 8.952/1994 e 9.307/1996) e também a Lei de Mediação (no 13.140/2015, juntamente com a Resolução 125/2010 do CNJ e o Código de Processo Civil.

É de fácil constatação que, na maioria das vezes, as decisões judiciais podem desagradar as partes, posto que são vinculantes e impositivas - ou seja, possuem força cogente. Em contrapartida, um acordo, propriamente dito, pelo fato de contar com a participação direta dos envolvidos torna-se mais facilmente assimilado e, sobretudo, espontaneamente cumprido.

Tendo em vista sua eficácia, a adoção dos métodos alternativos de solução de conflitos tem sido cada vez mais incentivada, inclusive, por exemplo, na esfera da Administração Pública, conforme dispõe o artigo 174, da legislação processual civil: "A União, os Estados, o Distrito Federal e os Municípios criarão câmaras de mediação e conciliação, com atribuições relacionadas à solução consensual de conflitos no âmbito administrativo (...)".

No mesmo sentido, a Lei de Arbitragem (Lei no 13.140/2015) prevê, em seu artigo 42, inclusive nas serventias extrajudiciais, o uso das formas consensuais para a resolução de litígios. O panorama burocrático e hereditário da função pública ligado às serventias tem sido paulatinamente alterado.

A qualificação dos profissionais por delegação bem como o emprego de novas formas de gestão e o aprimoramento de seus serviços através do uso de novas tecnologias contribuiu para um serviço eficaz e eficiente.

Por tais motivos, especialmente pela experiência afeta à desjudicialização, é que a supracitada lei abarcou a atuação das serventias extrajudiciais na resolução de conflitos através da mediação.

O Provimento 67 do CNJ, então órgão responsável pela administração do Judiciário e dos serviços notariais e de registro, dispõe sobre os procedimentos de 
conciliação e mediação no âmbito das serventias notariais e de registro de todas as unidades, sua facultatividade e a observância do notário ou registrador das disposições do ato normativo em questão, sem prejuízo do que dispõe a Lei no 13.140/2015.

Consoante o raciocínio de Flávia Pereira Hill (2018, p. 304), o referido Provimento "parece nos indicar que a mediação conduzida pelas serventias extrajudiciais "[...] se submete a um regime híbrido, um tertium genus". (grifo da autora)

É válido destacar que foram criados alguns requisitos para o exercício da função de mediador, como, por exemplo, a frequência em cursos de formação em escolas judiciais, além de cursos de atuação.

Em posicionamento contrário ao dispositivo supracitado, aponta Luiz Guilherme Loureiro (2019, p. 1352) que, tomando por base a atividade do notariado, a função exercida já se trata de um meio de solução de litígios.

Afirma que o notário é um mediador, por natureza, em virtude de seu ofício, complementado por seus conhecimentos jurídicos, que o habilitam no auxílio daqueles que o procuram para solucionar seus contratempos.

Assim, aduz que:

Embora seja inegável a utilidade da aprendizagem de determinadas técnicas multidisciplinares de negociação, de abordagem de problemas e de conciliação para a formação do mediador, a exigência de frequência de cursos oferecidos por escolas da magistratura ou instituições vinculadas à mediação judicial é despropositada e inova a Lei de Mediação, cujo art. $9^{\circ}$ dispõe que pode ser mediador qualquer pessoa capaz que tenha a confiança das partes e seja capacitada para fazer mediação, independentemente de integrar qualquer tipo de conselho, entidade de classe ou associação ou nele inscrever-se. (LOUREIRO, 2019, p. 1352).

Por outro lado, os notários e registradores, devem atuar observando os deveres de neutralidade, sigilo, imparcialidade e confidencialidade. Nesse último caso, há a exceção de quando se tratar de atos tipificados como crime de ação pública e informações a serem prestadas ao fisco e outros órgãos públicos, em consonância com a legislação pertinente. 
Ressalta-se que a função de mediador exercida pelo notário ou registrador segue a mesma regra referente aos impedimentos e exceções aplicáveis aos magistrados, previstos no Código de Processo Civil, em seus artigos 148, II, 167, §5º, 172 e 173, e na Lei de Arbitragem, em seus artigos $5^{\circ}$ ao $8^{\circ}$.

Dessa forma, o mediador não pode ser parente ou amigo íntimo de qualquer um dos envolvidos. Também fica impedido de atuar na função aquele que tiver atuado como representante das partes ou como testemunha em processos (judiciais ou arbitrais) que tenham relação com o litígio em voga. Constatadas tais circunstâncias após o início da arbitragem, o notário ou o registrador deve informar e fazer a devida interrupção.

No entanto, apesar das formalidades exigidas legalmente para o ato, evidencia-se que a vantagem da mediação nas serventias extrajudiciais, uma vez que é realizada em local à parte do fórum, demonstrando sua relevância através da experiência do atendimento ao público.

Hill (2018, p. 314) identifica, em rápida análise, que:

[...] o cidadão brasileiro médio sente certo temor reverencial ao adentrar no fórum, independentemente da providência que deva tomar naquele local. O simples fato de entrar no fórum, que é, por si só, um local formal, incute no cidadão essa percepção. $E$ ela se mostra profundamente deletéria para a mediação, pois prejudica a visualização de que esse método de solução de conflitos em pouco ou nada se identifica om a solução adjudicada estatal. Um ambiente informal, que deixe os mediandos à vontade, confortáveis para dialogar entre si de maneira franca, revelando seus reais interesses, de modo a permitir que o mediador verdadeiramente os auxilie a alcançar um acordo, afigura-se fundamental.

Por outro lado, conforme preceitua o artigo 10 do Provimento 67, estão autorizados a participar da mediação e da conciliação, como requerente ou requerido, a pessoa capaz, a pessoa jurídica e os entes despersonalizados a que a lei confere capacidade postulatória. Vale ressaltar que pode haver representação através de instrumento de mandato devidamente constituído, na forma pública ou particular, com poderes para transigir. 
Quanto ao objeto da mediação ou conciliação, pontua-se: deve se tratar de direito disponível ou de direito indisponível que admita transação. Nos ditames do artigo 725, III, do Código de Processo Civil, o termo de conciliação/mediação deverá ser submetido à homologação, podendo o procedimento versar sobre o conflito em sua integridade ou parcialmente.

O requerimento de conciliação/mediação pode ser dirigido a qualquer serventia extrajudicial, seja notarial ou de registro, conforme as respectivas competências. $O$ artigo 13 do Provimento 67 CNJ preceitua, ainda, que a formulação do supracitado requerimento poderá ser feita conjuntamente e firmada pelos interessados.

Tem-se como requisitos mínimos, conforme aduz o artigo 14: a qualificação do requerente, em especial, o nome ou denominação social, endereço, telefone e email de contato, número da carteira de identidade e do Cadastro de Pessoas Físicas (CPF) ou do Cadastro Nacional de Pessoa Jurídica (CNPJ) na Secretaria da Receita Federal, conforme o caso; dados suficientes da outra parte para que seja possível sua identificação e convite; a indicação de meio idôneo de notificação da outra parte; narrativa sucinta do conflito e, se houver, proposta de acordo; outras informações relevantes, a critério do requerente. Frisa-se que são de inteira responsabilidade do requerente a veracidade e correção dos dados fornecidos.

As serventias autorizadas para o procedimento podem disponibilizar um modelo-padrão de requerimento em seu site da rede mundial de computadores ou presencialmente (artigo $14, \S 1^{\circ}$, Provimento $67 \mathrm{CNJ}$ ).

Observados os requisitos, em voga, conforme explana o artigo 15, caso haja a constatação da ausência de alguma formalidade, o profissional notificará o requerente para que sane o vício no prazo de dez dias e, se necessário, marcará nova data para audiência. Persistindo o vício, será rejeitado o pedido, acarretando a inércia do requerente 0 arquivamento por ausência de interesse.

O artigo 16 aduz que a notificação da parte requerida será realizada por qualquer meio idôneo de comunicação, preferencialmente por meio eletrônico, por 
carta com AR ou notificação por oficial de registro de títulos e documentos do domicílio de quem deva recebê-la.

Luiz Guilherme Loureiro (2019, p. 1358) observa que:

Cabe ao mediador extrajudicial informar ao requerente os meios idôneos de comunicação permitidos e respectivos custos: a notificação feita por meio eletrônico é isenta de custos, enquanto as demais devem observar os valores cobrados pelos correios ou os emolumentos do serviço de registro de títulos e documentos. A notificação da parte requerida deve ser instruída com cópia do requerimento e esclarecimento de que sua participação na sessão de conciliação ou de mediação é facultativa, concedendose-lhe o prazo de 10 dias para que, querendo, indigne, por escrito, nova data e horário, caso não possa comparecer à sessão designada. O mediador pode, inclusive, manter contato com as partes no intuito de designar data de comum acordo para a sessão.

Durante o horário de atendimento ao público, é imprescindível que os serviços notariais e de registro autorizados mantenham, em suas dependências, um espaço reservado à realização das audiências.

O $\S 1^{0}$ do artigo 21 aponta que, realizado o chamamento nominal dos envolvidos, na data e hora designadas para a sessão de conciliação ou mediação, e, não constatado o seu comparecimento, o requerimento será arquivado.

Não se aplica o dispositivo, em tela, se preenchidos, cumulativamente, o seguinte: pluralidade de requerentes ou de requeridos, comparecimento de ao menos duas partes contrárias com o intuito de transigir; identificação formal da viabilidade de eventual acordo. A sessão de conciliação ou mediação terá eficácia apenas entre os que estiverem presentes.

Na hipótese de obtenção de acordo, deve ser lavrado termo de conciliação ou mediação e os indivíduos presentes assinarão a última folha do termo, rubricando as demais, conforme preceitua o artigo 22. A não obtenção do acordo, em contrapartida, nos termos do artigo 23 , não impede a realização de novas sessões. No tocante à desistência, o pedido será arquivado, independentemente de anuência da parte contrária.

Nesse ínterim, afirma-se que os serviços notariais e registrais devem providenciar livro de protocolo específico para o recebimento de requerimentos de 
conciliação e de mediação, que devem ser conservados de forma segura e permanente do arquivo da serventia. E, salvo determinação judicial em contrário, quaisquer diligências que exigirem a apresentação devem ser realizadas na sede do ofício.

No que se refere aos emolumentos, o artigo 36 orienta que estes se referem a uma sessão de mediação com duração de até sessenta minutos. Ultrapassado referido período temporal, serão cobrados emolumentos proporcionais, devendo o custo da mediação ser repartido pro rata entre as partes, exceto se convencionado de outra forma. Se as partes forem beneficiárias da justiça gratuita, o artigo 39 diz que o procedimento é isento de emolumentos.

Finalmente, o Provimento $67 \mathrm{CNJ}$ orienta os indivíduos no sentido de que é vedado às serventias extrajudiciais estabelecer, em documentos expedidos no ofício, cláusula compromissária de conciliação ou de mediação extrajudicial, aplicando, inclusive, à contagem dos prazos, no que couber, o disposto o artigo 132, caput e $\S 1^{\circ}$ da legislação civil brasileira.

Assim, temos que os notários e registradores podem colaborar, efetivamente, para a mitigação da cultura do litígio. A flexibilização desse paradigma confere uma solução mais célere, proporcionando, sobretudo, autonomia, diálogo, independência e satisfação às partes no exercício e garantia de seus direitos.

\section{CONSIDERAÇÕES FINAIS}

Por todo o exposto, vislumbra-se que as serventias extrajudiciais têm, por objetivo, o desenvolvimento equilibrado das relações jurídicas com a observância de normas e princípios a elas pertinentes, esquivando-se da eclosão de conflitos.

Através da segurança jurídica preventiva, então marco do sistema do notariado latino, adotado pelo Brasil, tabeliães e registradores, conferem autenticidade e formalização da vontade das partes, pautados pela neutralidade e sigilo.

As atividades exercidas por esses profissionais são configuradas pelo exercício de uma função pública sob a iniciativa privada. Ou seja, através da delegação conferida pelo Estado - marcada por sua perdurabilidade -, eles se tornam civilmente 
responsáveis por todos os prejuízos que, porventura, vierem a ser causados a terceiros. E não somente isso, suas funções estão submetidas ao crivo do controle estatal e sua competência não é passível de renúncia ou avocação.

Quanto ao controle de legalidade, fiscalização ou "qualificação", compreende-se o direito de obtenção da orientação mais adequada para fins de consecução do múnus notarial e registral, em consonância com a sistemática da administração pública e das garantias constitucionais. Pretende-se, com isso, o aprimoramento consecutivo do agente público que exerce poderes do Estado.

Além disso, ressalta-se a importância dos elementos imparcialidade e independência, através dos quais ocorre a equiparação e proteção dos direitos das partes - com a observância de situações peculiares, como, por exemplo as que denotam a condição de hipossuficiência.

Com base no modo de configuração das atividades ligadas às serventias extrajudiciais e com a percepção dos desafios trazidos pela morosidade da prestação jurisdicional pelo Estado, a extrajudicialização ou desjudicialização como forma de acesso à justiça veio à tona. Inclusive, positivada no caderno processual civil, com a previsão da solução de litígios pelas vias do Sistema de Justiça "Multiportas".

Paulatinamente, tem-se percebido as facilidades proporcionadas pelos serviços cartorários, mormente, no que se refere à adoção de métodos consensuais de solução de conflitos e celeridade nos atos que, anteriormente, eram realizados exclusivamente pelo Poder Judiciário. Outrossim, a possibilidade da livre escolha do tabelião ou registrador - ausência de regras de competência - proporcionou praticidade na aplicação do direito.

Não obstante, através dos dados estatísticos levantados no presente, é possível deduzir que as serventias extrajudiciais, além de nada custarem ao Estado, demonstram avanços progressivos na qualidade de seus serviços eletrônicos, além de expandir a confiabilidade dos cidadãos em seu ofício no dia a dia.

Isso pode ser visualizado através do salto no crescimento referente a atos, dentre outros, de substituição de prenome e sexo, reconhecimento de paternidade 
socioafetiva, divórcios, inventários, notificações extrajudiciais realizadas diretamente nos cartórios.

Depreende-se, portanto, que os instrumentos utilizados nessas serventias contribuem para a dinamicidade e aplicação de direitos na sistemática civilista, com a observância da lei e de critérios principiológicos, quais sejam, a isonomia, publicidade e segurança jurídica.

Com essa roupagem, e com a previsão já abordada, em 2015, na Lei de Arbitragem (Lei no 13.140/2015), pelo uso dos meios alternativos de solução de conflitos, inclusive, pelas serventias extrajudiciais, houve evidente alteração no panorama burocrático, que desencadeou a tessitura do Provimento no $67 / 2018$ pelo Conselho Nacional de Justiça.

A função de mediador, a ser exercida pelo tabelião ou oficial de registro, passa, então, a seguir a mesma regra quanto aos impedimentos e exceções aplicáveis aos magistrados. Além do que, revela a vantagem de ser exercida em local distinto do Fórum, em ambiente informal, contribuindo para o conforto das partes, para o diálogo e, consequentemente, para a participação mútua, obtendo maior facilidade no alcance do acordo.

Assim sendo, é fundamental que o Estado aprimore o acesso à Justiça, prezando pelo menor custo - eficiência - e maior celeridade nos trâmites. E não somente isso, é essencial que não se olvide de aplicar o direito, observando, em todos os casos, suas peculiaridades, as necessidades dos envolvidos e, especialmente, a tratativa das partes durante o procedimento. É válido lembrar que, mesmo com a evolução tecnológica e o aperfeiçoamento instrumental, o tratamento humanizado deve se fazer presente, em detrimento da automatização.

Conclui-se, por derradeiro, que o processo de desjudicialização proporcionado pelos serviços notariais e registrais importam um marco fundamental para a mitigação do paradigma da cultura do litígio, em complemento às atividades de mediação e conciliação já exercidas por outros profissionais com capacitação para tanto. 


\section{REFERÊNCIAS}

ASSUMPÇÃO, Letícia Franco Maculan. A atividade de controle e a função notarial e de registro. Disponível em: <http://www.notariado.org.br/blog/notarial/atividadede-controle-e-funcao-notarial-e-de-registro>. Acesso em: 28 fev. 2020.

BRASIL. Constituição da República Federativa do Brasil de 1988. Brasília: Presidência da República, 2019. Disponível em: <http://www.planalto.gov.br/ccivil_03/Constituicao/ Constituiçao.htm>. Acesso em: 28 fev. 2020.

BRASIL. Lei no 8.935 de 18 de novembro de 1994. Regulamenta o art. 236 da Constituição da República, dispondo sobre serviços notariais e de registro (Lei dos cartórios). Brasília: Presidência da República, 1994. Disponível em: <http://www.planalto.gov.br/ccivil_03/LEIS/L8935.htm>. Acesso em: 29 fev. 2020.

BRASIL. Lei no $\mathbf{1 0 . 4 0 6}$ de 10 de janeiro de 2002. Institui o Código Civil. Brasília: Presidência da República, 2002. Disponível em:

<http://www.planalto.gov.br/ccivil_03/leis/2002/l10406.htm>. Acesso em: 28 fev. 2020.

BRASIL. Lei n 13.105, de 16 de março de 2015. Código de Processo Civil. Brasília: Presidência da República, 2015. Disponível em:

<http://www.planalto.gov.br/ccivil_03/_ato2015-2018/2015/lei/l13105.htm>. Acesso em 28 fev. 2020.

BRASIL. Lei no 13.140 de 26 de junho de 2015. Dispõe sobre a mediação entre particulares como meio de solução de controvérsias e sobre a autocomposição de conflitos no âmbito da administração pública; altera a Lei n 9.469, de 10 de julho de 1997, e o Decreto no 70.235, de 6 de março de 1972; e revoga o § $2^{\circ}$ do art. $6^{\circ}$ da Lei no 9.469, de 10 de julho de 1997. Brasília: Presidência da República, 2015. Disponível em:

<http://www.planalto.gov.br/ccivil_03/_ato2015-2018/2015/lei/l13140.htm>. Acesso em 29 fev. 2020.

CAMPILONGO, Celso Fernandes. Função social do notariado: eficiência, confiança e imparcialidade. São Paulo: Saraiva, 2014.

Cartório em números. Disponível em:

<https://anoreg.org.br/anoregbr_file/Cart\%C3\%B3rio\%20em\%20N\%C3\%BAmeros. pdf>. Acesso em: 29 fev. 2020. 
COSTA FILHO, Venceslau Tavares et al. Direito notarial e registral. Coleção repercussões do Novo CPC, v. 11. Salvador: Juspodivm, 2016.

DEL GUÉRCIO NETO, Arthur; ROCHA JUNIOR, Gustavo Paula Leite; LAMANAUSKAS, Milton Fernando et al. $\mathbf{O}$ direito notarial e registral em artigos. vol. 2. 1. ed. São Paulo: YK Editora, 2017.

FISCHER, José Flávio Bueno. A intervenção do notário nos negócios privados como um instrumento de organização social justas e equilibrada e como um instrumento de equidade e inclusão social. Disponível em: <http://www.notariado.org.br/blog/notarial/intervencao-do-notario-nos-negociosprivados-como-um-instrumento-de-organizacao-social-justa-e-equilibrada-e-comoum-instrumento-de-equidade-e-inclusao-social>. Acesso em: 28 fev. 2020.

GUAGLIARIELLO, Thiago. A vocação natural das serventias extrajudiciais "cartórios" como ferramenta para a solução dos conflitos no âmbito extrajudicial. Disponível em: <http://www.notariado.org.br/blog/notarial/vocacaonatural-das-serventias-extrajudiciais-cartorios-como-ferramenta-para-solucao-dosconflitos-no-ambito-extrajudicial>. Acesso em: 29 fev. 2020.

HILL, Flávia Pereira. Mediação nos cartórios extrajudiciais: desafios e perspectivas. Disponível em: <https://www.e-publicacoes.uerj.br/index.php/redp/article/viewFile/39175/27450>. Acesso em 29 fev. 2020.

Justiça em números 2019. Conselho Nacional de Justiça. Brasília: CNJ, 2019. Disponível em: $<$ https://www.cnj.jus.br/wpcontent/uploads/conteudo/arquivo/2019/08/justica_em_numeros20190919.pdf>. Acesso em: 28 fev. 2020.

LOUREIRO, Luiz Guilherme. Registros públicos: teoria e prática. 10. ed. ver., atual. e ampl. Salvador: Juspodivm, 2019.

Provimento n⿳0 67 de 26/03/2018. Dispõe sobre os procedimentos de conciliação e de mediação nos serviços notariais e de registro do Brasil. Disponível em: <https://atos.cnj.jus.br/atos/detalhar/2532>. Acesso em 29 fev. 2020.

Resolução no 125, de 29/11/2010. Dispõe sobre a Política Judiciária Nacional de tratamento adequado dos conflitos de interesses no âmbito do Poder Judiciário e dá outras providências. Disponível em:

$<$ https://atos.cnj.jus.br/atos/detalhar/atos-normativos?documento=156>. Acesso em: 28 fev. 2020. 
Resolução no 35 de 24/04/2007. Disciplina a aplicação da Lei no 11.441/07 pelos serviços notariais e de registro. Disponível em:

< https://atos.cnj.jus.br/atos/detalhar/179>. Acesso em: 28 fev. 2020.

STF. Plenário. ADI 4275/DF, rel. orig. Min. Marco Aurélio, red. p/ o acórdão Min. Edson Fachin, julgado em 28/2 e 1\%/3/2018 (Info 892).

THEODORO JÚNIOR, Humberto. Curso de direito processual civil - teoria geral do direito processual civil, processo de conhecimento e procedimento comum. vol. 1. 56. ed. rev., atual. e ampl. Rio de Janeiro: Forense, 2015.

TJ-RJ - APL: 00001748320138190087 RIO DE JANEIRO ALCANTARA REGIONAL SAO GONCALO 2 VARA CIVEL, Relator: MAURICIO CALDAS LOPES, Data de Julgamento: 07/05/2014, DÉCIMA OITAVA CÂMARA CÍVEL. Data de Publicação: 08/05/2014.

TRF-3 - AMS: 00131486720154036100 SP, Relator: DESEMBARGADORA FEDERAL MÔNICA NOBRE, Data de Julgamento: 05/07/2017, QUARTA TURMA, Data de Publicação: e-DJF3 Judicial 1. Data de Publicação: 30/08/2017.

TRF-3 - AMS: 00131486720154036100 SP, Relator: DESEMBARGADORA FEDERAL MÔNICA NOBRE, Data de Julgamento: 05/07/2017, QUARTA TURMA, Data de Publicação: e-DJF3 Judicial 1. Data de Publicação: 30/08/2017. 